\title{
Toxicity and Antiviral Activities of Some Medicinal Plants Used by Traditional Medical Practitioners in Zimbabwe
}

\author{
Deniz Iklim Viol'1, Lameck Shoriwa Chagonda ${ }^{*}$, Sylvester Rodgers Moyo², \\ Ali Hikmet Mericli $^{3}$ \\ ${ }^{1}$ School of Pharmacy, College of Health Sciences, University of Zimbabwe, Harare, Zimbabwe \\ ${ }^{2}$ Faculty of Health and Applied Sciences, Namibia University of Science and Technology, Windhoek, Namibia \\ ${ }^{3}$ Department of Pharmacognosy, School of Pharmacy, University of Istanbul, Istanbul, Turkey \\ Email: "chagonda@medic.uz.ac.zw
}

Received 24 June 2016; accepted 7 August 2016; published 10 August 2016

Copyright (C) 2016 by authors and Scientific Research Publishing Inc.

This work is licensed under the Creative Commons Attribution International License (CC BY). http://creativecommons.org/licenses/by/4.0/

(c) (i) Open Access

\section{Abstract}

Genital herpes, usually caused by Herpes Simplex Virus type-2 (HSV-2), is the commonest sexually transmitted disease especially amongst rural women in Southern Africa including Zimbabwe. This predisposes them to HIV/AIDS infection, cancer and opportunistic infections (OIs). Current antiviral treatments are often cytotoxic and/or ineffective. This motivates active research to find alternative safer drugs or lead drugs from traditional medicinal sources. Twenty six (26) methanol extracts from commonly used and often endangered plant species (14) used by communities and traditional medical practitioners for treating illnesses and sexually transmitted diseases from 5-selected districts of Zimbabwe were investigated for toxicity by Brine shrimp lethality test (BSLT) and by $50 \%$ Cytopathic effect on VERO cultured cells. The extracts were also tested for antiviral activity against Herpes Simplex Virus-2 (HSV-2) by the End Point Titration Technique (EPTT) and Neutralisation Test (NT) on VERO cells. Results from the BSLTs ranged 66.66 - 4304 $\mu \mathrm{g} / \mathrm{ml} ; \mathbf{5 0 \%}$ Cytopathic effect from $19.53-312 \mu \mathrm{g} / \mathrm{ml}$ whilst the NT ID ${ }_{50}$ values ranged from 10.41 $125 \mu \mathrm{g} / \mathrm{ml}$. The antiviral EPTT reduction factor (RF) was $1-1^{4}$ with 13 extracts showing $R F \geq 10^{3}$. All the plant extracts had moderate to high toxicity $\left(\mathrm{LC}_{50}, 789-66 \mu \mathrm{g} / \mathrm{ml}\right)$ in the BSLT. Six extracts had $\mathrm{LC}_{50}$ values greater than $1000 \mu \mathrm{g} / \mathrm{ml}$. All 26 extracts were cytotoxic with $\mathrm{CC}_{50}$ values $<500$ $\mathrm{ug} / \mathrm{ml}$ of which 19 were more toxic $\mathrm{CC}_{50}<100 \mathrm{ug} / \mathrm{ml}$. Nine extracts had in vitro therapeutic indexes $\geq 3$ 3.7. Cassia abbreviata, Dichrostachys cinerea and Hypoxis hemerocallidea had therapeutic indexes (TI) 7.5 - 15.0. The more active plant extracts were from roots and root tubers. The results confirm the rationale for the use of traditional medicinal plants by traditional medical practitioners for treating various diseases and could bring awareness for their better use and improve

*Corresponding author.

How to cite this paper: Viol, D.I., Chagonda, L.S., Moyo, S.R. and Mericli, A.H. (2016) Toxicity and Antiviral Activities of Some Medicinal Plants Used by Traditional Medical Practitioners in Zimbabwe. American Journal of Plant Sciences, 7, 1538-1544. http://dx.doi.org/10.4236/ajps.2016.711145 
conservation. The results also provide an opportunity to develop more efficacious drugs by isolating lead compounds and determining their mode of action.

\title{
Keywords
}

\author{
Medicinal Plants, Toxicity, Antiviral Activity, Herpes Simplex Virus-2, Zimbabwe
}

\section{Introduction}

Third world countries are often endowed with rich flora and fauna which are put to good use in their traditional medical practices. Zimbabwe has over 5000 plant species of which 500 are established in Traditional Medicine (TM) since being legalised in 1981 through an Act of Parliament [1]. Traditional Medical Practitioners (TMPs) treat common illnesses and chronic diseases with claims to treat HIV/AIDS and opportunistic infections (OIs); this is not uncommon in Africa as a whole. Medicinal plants (MPs) still play a central role as sources of drugs for drug development into modern medicines and are still the mainstay for TMPs and for Complementary and Alternative Medicines (CAM) [2]-[4]. The combined effect of poverty and unemployment, civil unrest, land hunger and disease prevalence in developing countries has pushed more and more people towards the traditional medical practice. With over 55,000 registered TMPs in Zimbabwe alone, the protection of the 500 medicinal plants identified as playing a significant role in the traditional practice becomes a problem for conservationists [1]. The ever increasing demand for more land for agriculture and land reforms, human settlements, urban and industrial expansion has put many African governments on the back foot as they seek to address these challenges. Governments are therefore challenged to add value to MPs through research to achieve the multiple goals of conversation awareness and health improvement for the poor. Through technical initiatives, protocols, and/or encouragements, research into traditional medicine and medicinal plants is being pursued vigorously [5]. In Zimbabwe, a study was set up with the help of GEF/UNDP/MET (Ministry of Environment and Tourism) to carry out scientific laboratory studies on 50 extracts from 26 medicinal plants commonly used by communities to assess their conservation status in five selected districts from two regions of the country and to raise awareness of their importance and promote their sustainable use. Subsequently, we reported the antioxidant properties of extracts from these plant species [6] [7] as well as their antimicrobial and phytochemical properties [8] [9]. The laboratory studies confirmed the rationale for their use in traditional medical practice in line with other studies elsewhere to evaluate TMs targeted at finding alternative safer drugs to treat modern illnesses and to overcome growing resistance to infective agents. Our continuing research is now focused on selective studies and value addition through identifying active principles and action mechanisms [10] [11]. The HIV/AIDS virus still remain a threat to mankind and the current report presents the toxicity and antiviral properties of 14 plant species used in traditional medical practice which could have a bearing on the development of potential antiviral and anticancer drugs. This report highlights some of the key findings of the preliminary laboratory studies on toxicity and antiviral activities in the pilot study [12].

\section{Materials and Methods}

\subsection{Ethnobotanical Surveys and Plant Materials}

Ethno-botanical surveys on traditional medicinal plants used for treating common ailments, those most traded and threatened were carried out in five districts: Bulilima, Chimanimani, Chipinge, Mangwe and Matobo and the plants identified and authenticated by the National Herbarium and Botanic Gardens, Harare, as previously reported [8]. The plant materials roots, leaves, twigs, tuber, bark or whole, were dried, finely ground and stored.

\subsection{Preparation of Extracts for Bioactive Tests}

Selected plant parts were powdered (30 g), macerated in methanol (200 ml) [13], filtered and the filtrate evaporated off under reduced pressure, freeze dried and stored at $-20^{\circ} \mathrm{C}$. Part of the lyophilised extracts were dissolved in DMSO $(10 \mathrm{mg} / \mathrm{ml})$, filtered under aseptic conditions and stored for further bioactive use at $-20^{\circ} \mathrm{C}$. 


\subsection{Brine Shrimp Bioactivity Testing}

Bioactivity testing using the Brine Shrimp (Artemia salina) Lethality Test (BSLT) method was carried out in triplicate with different concentrations of the sterilized plant extracts in brine solution $(10 \mu \mathrm{g} / \mathrm{ml}-1000 \mu \mathrm{g} / \mathrm{ml})$ and the percentage lethality of the nauplii determined [14]. The concentration of the extract that kills $50 \%$ of the shrimps, "Lethal Concentration ${ }_{50}$ " $\left(\mathrm{LC}_{50}\right)$ values were recorded using Nerium oleander as the positive control by GraphPad Prism 5.0 linear regression and Pearson's two tailed analysis for 95\% confidence limits (95\% CI) [15].

\subsection{Cytotoxicity and Antiviral Activity of the Plant Extracts}

The lyophilized methanol extracts were dissolved in DMSO to a concentration of $10 \mathrm{mg} / \mathrm{ml}$. Vero cells (African green monkey kidney) (Highveld Ltd., South Africa) were grown and maintained in essential growth medium supplemented with $5 \%$ foetal calf serum and incubated under $5 \%$ carbon dioxide at $37^{\circ} \mathrm{C}$. The confluent cells were removed and trypsinated with phosphate buffered saline solution to achieve a cell concentration of $1-2 \times$ $10^{4}$ cells per well for VERO cells.

Herpes simplex virus 2 (HSV-2) (Highveld Ltd., South Africa) was propagated on Vero cells and the recovered virus suspension $(1 \mathrm{ml})$ diluted by infecting Vero confluent monolayers grown on microtitre plates with 0.1 $\mathrm{ml}$ of serial tenfold dilutions of the virus suspension quadruplicated and observed for 7 days for cytopathic effect (CPE). The HSV-2 virus titre was obtained from the $50 \%$ tissue culture infections dose per $\mathrm{ml}\left(\mathrm{TCID}_{50 / \mathrm{ml}}\right)[16]$.

Cytotoxicity of the different plant extracts that could cause non-specific cytopathic effect (CPE) on confluent Vero cells in growth medium was determined by using $100 \mathrm{ml}$ of serial two fold dilution of the plant extracts onto confluent Vero cells on microtitre plates in quadruplicate. The $50 \%$ cytotoxicity concentration $\left(\mathrm{CC}_{50}\right)$ was defined as the plant extract concentration causing 50\% CPE compared to uninfected cells [16]. The maximum nontoxic dilution (MNTD) was taken as the next dilution after the TCID ${ }_{50}$ of the plant extract and used for the antiviral assays.

\subsection{Antiviral Assays}

Antiviral assays were carried out using the Neutralization test (NT) to determine non-cytotoxic concentration $\left(\mathrm{ID}_{50}\right)$ that inhibits/protects $50 \%$ of the monolayer cells against destruction by the virus compared to uninfected cells using the Spearman-Karber formula [17] and by the End point titration technique (EPTT) [18]. In the EPPT assay, confluent monolayer Vero cells were grown on 96-well microtitre plates with the medium removed from the wells. $0.05 \mathrm{ml}$ (MNTD) of the plant extract and $0.05 \mathrm{ml}$ of growth maintenance medium followed $1 \mathrm{~h}$ later by $0.05 \mathrm{ml}$ of tenfold HSV-2 serial diluted virus suspension and the mixture incubated at $37^{\circ} \mathrm{C}$. Controls consisted of Vero cells infected with virus and not treated with plant extract and virus uninfected and untreated cells. All tests were compared with a positive control, acyclor (Sigma). The antiviral activity was determined as the reduction factor (RF) of the viral titre: the ratio of virus titre in the absence and presence of the plant extract. A promising antiviral has a $\mathrm{RF} \geq 10^{3}$ [13] [18].

\section{Results and Discussion}

\subsection{Brine Shrimp Bioactivity Testing}

The bioactivity of the plant extracts using the Brine shrimp lethality test (BSLT) indicated that plants in this category were relatively toxic with 15 of the 26 extracts recording $\mathrm{LC}_{50}<500 \mu \mathrm{g} / \mathrm{ml}$ (Table 1). Only 6 extracts had $\mathrm{LC}_{50}>1000 \mu \mathrm{g} / \mathrm{ml}$. Potentially very toxic plants were $T$. sericea $\left(\mathrm{LC}_{50}=66.7 \mu \mathrm{g} / \mathrm{ml}\right)$ and $\mathrm{K}$. africana $\left(\mathrm{LC}_{50}\right.$ $=117.4 \mu \mathrm{g} / \mathrm{ml})$ showing greater toxicity than the positive control $N$. oleander $\left(\mathrm{LC}_{50}=141.7 \mu \mathrm{g} / \mathrm{ml}\right)$. The BSLT bioassay is widely used as a basic screening test for toxicity in prospecting for suspected biological activity in crude and isolated plant extracts from traditional folklore [4] [14] [15] [19]-[22].

\subsection{Cytotoxicity and Antiviral Activity}

Cytotoxicity effects for the extracts on Vero cells showed all 26 extracts had $\mathrm{CC}_{50}<500 \mathrm{ug} / \mathrm{ml}$, 19 with $\mathrm{CC}_{50}<$ $100 \mathrm{ug} / \mathrm{ml}$ and 12 with $\mathrm{CC}_{50}<50 \mathrm{ug} / \mathrm{ml}$ (Table 1) indicating potential antitumour and/or antiviral activity. Antiviral screening tests indicated some plant extracts possess potential activities to protect the cells against HSV-2 
Table 1. Plants chosen for toxicity and antiviral tests.

\begin{tabular}{|c|c|c|c|c|c|c|c|}
\hline No & Species, family name, voucher number, status & $\begin{array}{c}\text { Plant } \\
\text { part }\end{array}$ & $\begin{array}{l}\text { BSLT } \\
\text { LC } 50 \\
(\mathrm{ug} / \mathrm{ml})\end{array}$ & $\begin{array}{l}\mathrm{CC}_{50} \\
(50 \% \mathrm{CPE}) \\
\text { (ug/ml) }\end{array}$ & $\begin{array}{l}\text { NT-ID } \\
\text { (ug/ml) }\end{array}$ & $\begin{array}{l}\text { TI: } \\
\mathrm{CC}_{50} / \mathrm{ID}_{50}\end{array}$ & $\begin{array}{l}\text { EPTT } \\
\left(\mathrm{RF}^{\mathrm{b}}\right)\end{array}$ \\
\hline 1 & $\begin{array}{c}\text { Cassia abbreviate Oliv., Fabaceae (2721): } \\
\text { Cm. } \\
\text { Status: } \mathrm{Cm}\end{array}$ & $\begin{array}{l}\text { lf } \\
\text { rt } \\
\text { bk }\end{array}$ & $\begin{array}{c}454.93 \pm 18.60 \\
445.72 \pm 22.15 \\
1319.37 \pm 356.63\end{array}$ & $\begin{array}{l}156.25 \\
156.25 \\
39.06\end{array}$ & $\begin{array}{c}20.83 \\
10.41 \\
\text { NA }\end{array}$ & $\begin{array}{c}7.5 \\
15.0 \\
-\end{array}$ & $\begin{array}{c}10^{2} \\
10^{3} \\
1\end{array}$ \\
\hline 2 & $\begin{array}{l}\text { Dichrostachys cinerea (L.) } \\
\text { Wight and Arn. } \\
\text { Mimosaceae (32): Cm. }\end{array}$ & $\begin{array}{l}\text { If } \\
\text { rt }\end{array}$ & $\begin{array}{c}539.39 \pm 78.24 \\
4304.59 \pm 685.69\end{array}$ & $\begin{array}{c}78.13 \\
312.50\end{array}$ & $\begin{array}{l}10.41 \\
83.33\end{array}$ & $\begin{array}{l}7.5 \\
3.7\end{array}$ & $\begin{array}{l}10^{4} \\
10^{2}\end{array}$ \\
\hline 3 & $\begin{array}{l}\text { Elaedendron matabelicum (Loes). Steedman } \\
\text { Celastraceae (2121): Th., Endemic }\end{array}$ & rt & $1012.31 \pm 217.69$ & 78.13 & NA & - & 1 \\
\hline 4 & $\begin{array}{c}\text { Elephantorrhiza goetzei } \\
\text { Harms. Fabaceae (7136): Th. }\end{array}$ & rt & $356.55 \pm 24.55$ & 156.25 & 83.33 & 1.9 & $10^{2}$ \\
\hline 5 & $\begin{array}{l}\text { Flacourtia indica (Burm. f.) } \\
\text { Merr. Flacourticaceae (57/62): Th. }\end{array}$ & $\begin{array}{l}\text { lf } \\
\text { rt }\end{array}$ & $\begin{array}{l}281.81 \pm 26.14 \\
467.31 \pm 39.01\end{array}$ & $\begin{array}{c}78.13 \\
156.25\end{array}$ & $\begin{array}{c}83.33 \\
125.00\end{array}$ & $\begin{array}{l}0.9 \\
1.3\end{array}$ & $\begin{array}{l}10^{2} \\
10^{3}\end{array}$ \\
\hline 6 & $\begin{array}{l}\text { Gymnosporia senegalensis (Lam.) } \\
\text { Loes. Celastraceae (15): Cm. }\end{array}$ & $\begin{array}{l}\text { lf } \\
\mathrm{rt} \\
\mathrm{tw}\end{array}$ & $\begin{array}{c}789.37 \pm 104.06 \\
2185.61 \pm 872.25 \\
754.70 \pm 182.57\end{array}$ & $\begin{array}{l}39.06 \\
78.13 \\
19.53\end{array}$ & $\begin{array}{l}10.41 \\
20.83 \\
15.63\end{array}$ & $\begin{array}{l}3.8 \\
3.8 \\
1.2\end{array}$ & $\begin{array}{l}10^{3} \\
10^{3} \\
10^{3}\end{array}$ \\
\hline 7 & $\begin{array}{c}\text { Hypoxis hemerocallidea Fisch. } \\
\text { \& Ave'-Lall. Hypoxidaceae (MTDV06): Th. }\end{array}$ & tb & $735.34 \pm 89.39$ & 156.25 & 10.41 & 15.0 & $10^{3}$ \\
\hline 8 & $\begin{array}{l}\text { Khaya anthotheca (Welw.) } \\
\text { DC. Meliaceae (892): Cm. }\end{array}$ & bk & $482.19 \pm 43.49$ & 39.06 & 31.25 & 1.2 & $10^{2}$ \\
\hline 9 & $\begin{array}{l}\text { Kigelia africana (Lam.) } \\
\text { Benth. Bignoniaceae (5990): Cm. }\end{array}$ & $\begin{array}{l}\mathrm{bk} \\
\mathrm{ft} \\
\mathrm{rt}\end{array}$ & $\begin{array}{l}262.20 \pm 25.07 \\
117.41 \pm 30.27 \\
501.35 \pm 34.88\end{array}$ & $\begin{array}{l}39.06 \\
39.06 \\
39.06\end{array}$ & $\begin{array}{c}31.25 \\
31.25 \\
\text { NA }\end{array}$ & $\begin{array}{c}1.2 \\
1.2 \\
-\end{array}$ & $\begin{array}{c}10^{3} \\
10^{4} \\
1\end{array}$ \\
\hline 10 & $\begin{array}{l}\text { Rhuschirindensis Baker f. } \\
\text { Anacardiaceae (103/67): Cm. }\end{array}$ & $\begin{array}{l}\text { lf } \\
\text { rt }\end{array}$ & $\begin{array}{c}1023.26 \pm 161.69 \\
316.60 \pm 30.07\end{array}$ & $\begin{array}{c}312.50 \\
78.13\end{array}$ & $\begin{array}{c}\text { NA } \\
20.83\end{array}$ & - & $\begin{array}{c}1 \\
10^{2}\end{array}$ \\
\hline 11 & $\begin{array}{c}\text { Sclerocarya birrea (A. Riich.) } \\
\text { Hochst. Anacardiaceae (3114): Th, Cm. }\end{array}$ & bk & $1112.37 \pm 210.04$ & 39.06 & 20.83 & 1.9 & $10^{3}$ \\
\hline 12 & $\begin{array}{l}\text { Securidaca longepedunculata } \\
\text { Fresen. Polygalaceae (264/59): V Th. }\end{array}$ & rt & $351.89 \pm 35.70$ & 78.13 & 20.83 & 3.8 & $10^{3}$ \\
\hline 13 & $\begin{array}{l}\text { Terminalia sericea Burch. Ex. } \\
\text { DC. Combretaceae (5): Th., endemic }\end{array}$ & $\begin{array}{l}\text { lf } \\
\text { rt }\end{array}$ & $\begin{array}{c}66.66 \pm 49.31 \\
295.33 \pm 37.19\end{array}$ & $\begin{array}{l}39.06 \\
39.06\end{array}$ & $\begin{array}{l}31.25 \\
20.83\end{array}$ & $\begin{array}{l}1.2 \\
1.9\end{array}$ & $\begin{array}{l}10^{2} \\
10^{3}\end{array}$ \\
\hline 14 & $\begin{array}{c}\text { Warburgia salutaris (Bertol.f.) } \\
\text { Chiov. Canellaceae (CPDV06): V Th. }\end{array}$ & $\begin{array}{l}\text { lf } \\
\text { rt } \\
\text { bk }\end{array}$ & $\begin{array}{l}351.41 \pm 29.58 \\
426.10 \pm 55.55 \\
359.66 \pm 14.33\end{array}$ & $\begin{array}{l}78.13 \\
39.06 \\
19.53\end{array}$ & $\begin{array}{l}\text { NA } \\
31.25 \\
\text { NA }\end{array}$ & $\begin{array}{c}- \\
1.2 \\
-\end{array}$ & $\begin{array}{c}1 \\
10^{3} \\
1\end{array}$ \\
\hline 15 & Nerium oleander (ref-positive control) & lf & $141.67 \pm 68.15$ & & Acylor-1.50 & & \\
\hline
\end{tabular}

Plant part investigated: lf = leaf; rt = root; tb = tuber; bk = bark; Environmental status S: Cm = common; Th = threatened; VTh = very threatened; BSLT, Brine shrimp lethality test $\mathrm{LC}_{50}$, lethal concentration that kills $50 \%$ of the shrimps with corresponding $95 \%$ confidence intervals (95\% CI); $\mathrm{CC}_{50}(50 \% \mathrm{CPE})$, plant extract cytotoxicity concentration that kills 50\% tissue cells; NT, neutralisation test: NA = no activity; ID 50 , non-cytotoxic

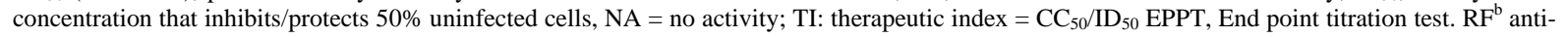
viral reduction factor: ratio of viral titre of control in absence of extract over viral titre in presence of extract.

induced destruction with EPTT reduction factors $(\mathrm{RFs}) \geq 10^{3}$ (Table 1). D. cinerea $\left(\mathrm{RF}=10^{4}\right)$ and $K$. Africana $\left(\mathrm{RF}=10^{4}\right)$ were particularly active, however, most plants in the group had RFs $\geq 10^{3}$ which activities were also mirrored in the neutralization test $(\mathrm{NT}) \mathrm{ID}_{50} \mathrm{~S}$ where acyclovir the positive control had $\mathrm{ID}_{50}=1.5$. G. senegalensis, $T$. sericea and $W$. salutaris previously noted for their high antimicrobial activities [8] were also in the group of potential antiviral plants with high cytotoxicities $\left(\mathrm{CC}_{50}<50 \mu \mathrm{g} / \mathrm{ml}\right)$ and high reduction factors $\left(\mathrm{RF}=10^{3}\right)$ for some of their extracts. However, in addition to having a high reduction factor, a plant extract should also have a high therapeutic index (TI)/high sensitivity value in order to prevent cell destruction and be considered for further potential antiviral investigation. From this group (Table 1), Cassia abbreviata had TI values of 7 and 15 for leaf and root extract respectively, Dichrostachys cinerea TI $=7.5$ for leaf extract and Hypoxis rooperi had TI = 15 for the tuber. Kigelia fruit showed a high reduction factor $10^{4}$ but low therapeutic efficacy 1.2 in line with other reports where its anti-tumour and other biological properties are highlighted [21]-[28]. Plant extracts 
Gymnosporia senegalensis (Celastraceae), Warburgia salutaris (Canellaceae) and Terminalia sericea (Combretaceae) are popular plants in traditional practice. Recent studies are focusing on the toxicity, antiviral and antitumor properties of crude and isolates against different viral species especially HIV-1, HSV-1, HSV-2, antiDengue [29]-[38]. In general, all the plants in this study displayed both antiinfective and toxic properties (Table 1) whilst reports from phytochemical studies reflect flavonoids and condensed tannins largely responsible for the observed antiviral and anticancer activities [25]-[28] [38] [39]. Isolated fractions and derivatives can have greater toxicity and/or activity than the crude extracts, the case of artemisinin from Artemisia annua in the treatment of malaria [39] and the isolated phytoconstituents from Kigelia and Hypoxis species [24]-[27].

\section{Conclusion}

Sub-Saharan Africa still suffers the great burden for HIV/AIDS with millions infected and affected. Though prevalence has fallen, availability of antiviral drugs poses a continuing challenge. The use of TMPs is often plagued with issues of safety and/or toxicity. The antimicrobial and antiviral activities demonstrated by the plant extracts are further proof to support claims by TPs of their ability to treat more serious illness including HIV/ AIDS and opportunistic infections [5]. Studies carried out from cited literature on traditional medicinal plants elsewhere have also demonstrated their potential antimicrobial and antiviral activities. Whilst the laboratory studies and biological results confirm traditional folkloric uses, their application in modern medicine has enormous challenges with respect to the standardisation of crude extracts, isolation and characterisation of key active principles and the adoption of clinical protocols gave the wide range of related plant species in different countries. This may not be helped by the lack of sponsorship for such research gave the poor state of the economies of most developing countries. In some cases, the active principles and their derivatives have proven more active than their crude extracts: artemisinin and derivatives (from Chinese Artemisia annua) [39] in the treatment of malaria; sitosterols, hypoxoside and rooperol (from African Hypoxis spp.) in the treatment of prostate cancer [25]. Likewise extracts from D. cinerea and C. abbreviata (Fabaceae), Kigelia africana (Bignoniaceae) and T. sericea (Combretaceae) should be studied for active principles, derivatives and followed by pre-clinical trials possible due to the wide spectrum of activities for isolates. The wide geographical variables make this some task but regions can adopt standards consistent with their findings from the wild where they are endemic or from propagation efforts where these are applicable. Our studies focused on local plants and reported wide scientific data which should attract more research. Such increased research activity has the potential to promote traditional medical practice by value addition to the medicinal plants used to treat patients, improve quality standards and the formulation of traditional remedies, bring awareness to the environmental status of TMPs and create opportunities for further development of TMPs into modern medicines.

\section{Acknowledgements}

The authors would like to thank GEF/UNDP through the Ministry of Environment and Tourism (MET) for supporting two postgraduate students on the project, the local communities and traditional practitioners from the districts involved, the School of Pharmacy and the Research Board of the University of Zimbabwe and other national institutions for making this work possible through many linkages and collaborations.

\section{References}

[1] Chavunduka, G.L. (1997) Traditional Medicine in Modern Zimbabwe, Harare. University of Zimbabwe Publications, Harare.

[2] Breyer-Brandwijk, M.G. and Watt, J.M. (1962) The Medicinal and Poisonous Plants of Southern and Eastern Africa. 2nd Edition, E. and S. Livingstone Ltd., Edinburgh.

[3] Gelfand, M., Mavi, M., Drummond, R.B. and Ndemera, N. (1998) Traditional Medical Practitioners in Zimbabwe. Mambo Press, Gweru.

[4] Hostettmann, K., Marston, A., Ndjoko, K. and Wolfender, J.L. (2000) The Potential of African Plants as a Source of Drugs. Current Organic Chemistry, 4, 973-1010. http://dx.doi.org/10.2174/1385272003375923

[5] Mumba, E.M., Ed. (2007) Introduction to the NEPAD/Southern African Network for Biosciences. Proceedings of the First NEPAD/SANBIO Workshop on Scientific Validation of Traditional Medicine for Affordable Treatments of HIV/AIDS and Opportunistic Infections, Lusaka, 15-16 March 2007, 9-11.

[6] Munodawafa, T., Chagonda, L.S., Viol, I., Muchuweti, M. and Moyo, R.S. (2010) Total Phenolic Content and Anti- 
oxidant Activity of Some Zimbabwean Traditional Medicinal Plants. Recent Progress in Medicinal Plants, Drug Plants III, 29, 364-373.

[7] Viol, D.I., Chagonda, L.S., Munodawafa, T., Muchuweti, M.M., Moyo, S.R. and Mericli, A.H. (2013) Antioxidant Activity and Total Phenolic Contents of some Traditional Medicinal Plants from Zimbabwe. Journal of Biologically Active Products from Nature, 3, 345-352. http://dx.doi.org/10.1080/22311866.2013.782753

[8] Viol, D.I., Chagonda, L.S., Moyo, S.R. and Mericli, A.H. (2013) Antibacterial, Antifungal and Phytochemical Activities of Some Medicinal Plants from Zimbabwe. Journal of Biologically Active Products from Nature, 3, $273-284$. http://dx.doi.org/10.1080/22311866.2013.782758

[9] Munodawafa, T., Chagonda, L.S. and Moyo, S.R. (2013) Antimicrobial and Phytochemical Screening of Some Zimbabwean Medicinal Plants. Journal of Biologically Active Products from Nature, 3, 323-330. http://dx.doi.org/10.1080/22311866.2013.782759

[10] Munodawafa, T., Tagwireyi, D., Gadaga, L., Gomo, E., Bierman, F. and Chagonda, L.S. (2015) Acute and Subacute Oral Toxicity of Hydroethanolic Root Extract of Annona stenophyla Engl. and Diels in Sprague Dawley Rats. Journal of Biologically Active Products from Nature, 5, 349-356. http://dx.doi.org/10.1080/22311866.2015.1110501

[11] Taderera, T., Chagonda, L.S., Gomo, E. and Shai, L.J. (2015) Inhibitory Activity of $\alpha$-Glucosidase and $\alpha$-Amylase by Annona stenophyllaroot Extract as Mechanism for Hypoglycaemic Control of DM. International Journal of Pharmacy, Photon, 106, 436-444.

[12] Viol, D.I. (2013) Screening of Traditional Medicinal Plants from Zimbabwe for Phytochemistry, Antioxidant, Antimicrobial, Antiviral and Toxicological Activities. http://ir.uz.ac.zw/jspui/bitstream/10646/1105/1/Viol_thesis.pdf

[13] Betancur-Galvis, L.A., Morales, G.E., Forero, J.E. and Roldan, J. (2002) Cytotoxic and Antiviral Activities of Colombian Medicinal Plant Extracts of the Euphorbia Genus. Memorial Institute Oswaldo Cruz, 97, 541-546. http://dx.doi.org/10.1590/s0074-02762002000400017

[14] McLaughlin, J.L., Chang, C.J. and Smith, D.L. (1991) Bench-Top Bioassays for the Discovery of Bioactive Natural Products: An Update. In: Rhaman, A.U., Ed., Studies in Natural Products Chemistry, Elsevier, Amsterdam, 383-409.

[15] Krishnaraju, A.V., Tayi Rao, V.N., Sundararaju, D., Vanisree, M., Tsay, H.S. and Subbaraju, G.V. (2006) Biological Screening of Medicinal Plants Collected from Eastern Ghats of India Using Artemiasalina (Brine Shrimp Test). International Journal of Applied Science and Engineering, 2, 115-125.

[16] Reed, L.J. and Muench, H. (1938) A Simple Method of Estimating Fifty Percent Endpoints. American Journal of Hygiene, 27, 493-497.

[17] Villegas, P. and Purchase, H.G. (1983) Titration of Biological Suspensions. In: Hitchner, S.B., Domermuth, C.H., Purchase, H.G. and Williams, J.E., Eds., Isolation and Identification of Avian Pathogens, 2nd Edition, The American Association of Avian Pathologists, 124-128.

[18] Vlietinck, A.J., van Hoof, L., Totte, J., Lasure, A., van den Berghe, D., Rwangabo, P.C. and Mvukiyumwami, J. (1995) Screening of Hundred Rwandese Medicinal Plants for Antimicrobial and Antiviral Properties. Journal of Ethnopharmacology, 46, 31-47. http://dx.doi.org/10.1016/0378-8741(95)01226-4

[19] Mongalo, N.I. and Mafoko, B.J. (2013) Cassia abbreviate Oliv. A Review of Its Ethnomedicinal Uses, Toxicology, Phytochemistry, Possible Propagation Techniques and Pharmacology. African Journal of Pharmacy and Pharmacology, 7, 2901-2906. http://dx.doi.org/10.5897/AJPP12.1017

[20] Gadir, S.A. (2012) Assessment of Bioactivity of Some Sudanese Medicinal Plants Using Brine Shrimp (Artemisia salina) Lethality Assay. Journal of Chemical and Pharmaceutical Research, 4, 5145-5148.

[21] Maregesi, S.M., Pieters, L., Ngassapa, O.D., Apers, S., Vingerhoets, R., Cos, P., Vanden Berge, D.A. and Vlietinck, A.J. (2008) Screening of Some Tanzanian Medicinal Plants from Bunda District for Antibacterial, Antifungal and Antiviral Activities. Journal of Ethnopharmacology, 119, 58-66. http://dx.doi.org/10.1016/j.jep.2008.05.033

[22] Moshi, M.J., Mbwambo, Z.H., Kapingu, M.C., Mhozya, V.H. and Marwa, C. (2006) Antimicrobial and Brine Shrimp Lethality of Extracts of Terminalia mollis Laws. African Journal of Traditional Complementary and Alternative Medicines, 3, 59-69. http://dx.doi.org/10.4314/ajtcam.v3i3.31166

[23] Mathabe, M.C., Nikolova, R.V., Lall, H. and Nyazema, N.Z. (2006) Antibacterial Activities of Medicinal Plants Used for the Treatment of Diarrhoea in Limpopo Province, South Africa. Journal of Ethnopharmacology, 105, 286-293. http://dx.doi.org/10.1016/j.jep.2006.01.029

[24] Drewes, S.E., Elliot, E., Khan, F., Dlamini, J.T.B. and Gcumisa, M.S.S. (2008) Hypoxis hemerocallidea-Not Merely a Cure for Benign Prostate Hyperplasia. Journal of Ethnopharmacology, 119, 593-598. http://dx.doi.org/10.1016/j.jep.2008.05.027

[25] Ncube, B., Ndlala, A.R., Okem, A. and van Staden, J. (2013) Hypoxis (Hypoxidaceae) in African Traditional Medicine. Journal of Ethnopharmacology, 150, 818-827. http://dx.doi.org/10.1016/j.jep.2013.10.032

[26] Amusan, O.O.G., Sukati, N.A., Dlamini, P.S. and Sibandze, F.G. (2007) Some Swazi Phytomedicines and Their Con- 
stituents. African Journal of Biotechnology, 6, 267-272.

[27] Arkhipov, A., Sirdaarta, J., Raya, P., McDonnell, P.A. and Cook, I.E. (2014) An Examination of the Antibacterial, Antifungal, Anti-Gardial and Anticancer Properties of Kigelia africana Fruit Extracts. Pharmacognosy Communications, 4, 62-76. http://dx.doi.org/10.5530/pc.2014.3.7

[28] Neondo, J.O., Mbithe, C.M., Njenga, P.K. and Muthuri, W. (2012) Phytochemical Characterisation, Antibacterial Screening and Toxicity Evaluation of Dichrostachys cinerea. International Journal of Medicinal Plant Research, 1, 32-37.

[29] Bessong, P.O., Obi, C.L., Igumbor, E., Andreola, M.L. and Litvak, S. (2004) In Vitro Activity of Three Selected South African Medicinal Plants against HIV Type 1 Reverse Transcriptase. African Journal of Biotechnology, 3, 555-559. http://dx.doi.org/10.5897/AJB2004.000-2109

[30] Bessong, P.O., Obi, C.L., Andreola, M.L., Rojas, L.B., Pouysegu, L., Igumbor, E., Meyer, J.J.M., Quideau, S. and Litvak, S. (2005) Evaluation of Selected South African Medicinal Plants for Inhibitory Properties against Human Immunodeficiency Virus Type 1 Reverse Transcriptase and Integrase. Journal of Ethnopharmacology, 99, 83-91. http://dx.doi.org/10.1016/j.jep.2005.01.056

[31] Müller, V., Chavez, H., Reginatto, F.H., Zucolotto, S.M., Niero, R., Navarro, D., Yunes, R.A., Schenkel, E.P., Barardi, C.R.M., Zanetti, C.R. and Simoes, C.M.O. (2007) Evaluation of Antiviral Activity of South American Plant Extracts against Herpes Simplex Virus Type 1 and Rabies Virus. Phytotherapy Research, 21, 970-974.

[32] Rajhandari, M., Mentel, R., Jha, P.K., Chaudhary, R.P., Bhattarai, S., Gevali, M.B., Karmachya, N., Hipper, M. and Lindequist, U. (2007) Antiviral Activity of Some Plants Used in Nepalese Traditional Medicine. Evidence Based Complementary and Alternative Medicine, 6, 517-522.

[33] Abad, M.J., Guerra, J.A., Bermejo, P., Irurzun, A. and Carrasco, L. (2000) Search for Antiviral Activity in Higher Plants. Phytotherapy Research, 14, 604-667. http://dx.doi.org/10.1002/1099-1573(200012)14:8<604::AID-PTR678>3.0.CO;2-L

[34] Verma, H., Patil, P.R., Kolhapure, R.M. and Gopalkrishna, V. (2008) Antiviral Activity of the Indian Medicinal Plant Extract, Swertia chirata against Herpes Simplex Viruses: A Study by in Vitro and Molecular Approach. Indiana Journal of Medical Microbiology, 26, 322-326. http://dx.doi.org/10.4103/0255-0857.43561

[35] Spindola, K.C.W., Simas, N.K., Salles, T.S., Meneses, M.D.F., Sato, A., Ferreira, D., Romao, W. and Kuster, R.M. (2014) Anti-Mayaro Virus Activity of Cassia australis Extracts (Fabaceae, Leguminosa). Parasites \& Vectors, 7, 537. http://dx.doi.org/10.1186/s13071-014-0537-z

[36] Nandi, C.S., Sharon, A., Sarkar, M.C., Chakabarti, S. and Chattopadhyay, D. (2013) An Indole Alkaloid from Tribal Folklore Inhibits Immediate Early Event in HSV-2 Infected Cells with Therapeutic Efficacy in Vaginally Infected Mice. PLoS ONE, 8, e77937. http://dx.doi.org/10.1371/journal.pone.0077937

[37] Tang, L.I.C., Ling, A.P.K., Koh, R.Y., Chye, S.M. and Voon, K.G.L. (2012) Screening of Anti-Dengue Activity in Methanolic Extracts of Medicinal Plants. BMC Complementary and Alternative Medicine, 12, 3. http://dx.doi.org/10.1186/1472-6882-12-3

[38] Swain, S.S. and Dubey, J. (2013) Anti-Dengue Medicinal Plants: A Mini-Review. Research and Reviews: Journal of Pharmacognosy and Phytochemistry, 1, 5-9.

[39] De Ridder, S., van der Kooy, F. and Verpoorte, R. (2008) Artemisia annua as Self Reliant Treatment in Developing Countries. Journal of Ethnopharmacology, 120, 302-314. http://dx.doi.org/10.1016/j.jep.2008.09.017 


\section{Submit or recommend next manuscript to SCIRP and we will provide best service for you:}

Accepting pre-submission inquiries through Email, Facebook, LinkedIn, Twitter, etc.

A wide selection of journals (inclusive of 9 subjects, more than 200 journals)

Providing 24-hour high-quality service

User-friendly online submission system

Fair and swift peer-review system

Efficient typesetting and proofreading procedure

Display of the result of downloads and visits, as well as the number of cited articles

Maximum dissemination of your research work

Submit your manuscript at: http://papersubmission.scirp.org/ 